\title{
The Incidence of Social Security Payroll Taxes: Evidence From China
}

\author{
Xinxin $\mathrm{Ma}^{1}$ \& Dongyang Zhang ${ }^{2}$ \\ ${ }^{1}$ Institute of Economic Research, Hitotsubashi University, Tokyo, Japan \\ ${ }^{2}$ School of Economics, Capital University of Economics and Business, Beijing, China \\ Correspondence: Xinxin Ma, Institute of Economic Research, Hitotsubashi University, Tokyo, Japan.
}

Received: June 25, 2018

Accepted: August 19, 2018

Online Published: Augus 21, 2018

doi:10.5430/ijfr.v9n4p1

URL: https://doi.org/10.5430/ijfr.v9n4p1

\begin{abstract}
The Chinese government enforced public security system reform in the economic transition period. Now, the enterprise' social insurance premium, a kind of payroll tax, is nearly $40 \%$ of the total wage in China. It is thought enterprises may transfer the burden of payroll taxes to workers by reducing their wages. Does the level of an enterprise's social security payroll taxes influence their workers' wages? Using the Chinese Large and Medium-size Manufacturing Enterprises (CLMME) dataset to construct an enterprise panel data from 2004 to 2007, we employ an empirical study to provide evidence on the issue. We utilize the fixed effects model, random effects model and Generalized Method of Moments (GMM) method to address the heterogeneity problem, initial dependent problem and endogenous problem. It is found that in general, increased social security payroll taxes negatively affect the workers' wages, which indicates that many enterprises may transfer the payroll taxes burden onto their workers. Increased social security payroll taxes may decrease the wage levels for workers in both the public sector and the private sector, but the negative effect is greater for workers in the private sector than in the public sector.
\end{abstract}

Keywords: payroll tax, wage, public sector, private sector, China

\section{Introduction}

In China, during the economic transition period (the period after 1977), the public security systems changed from government security to social security insurance as the state owned enterprises (SOEs) were reformed. The government security systems were replaced with social security systems for the SOEs. In addition, during this period, the private sector, including privately owned enterprises (POEs) and foreign owned enterprises (FOEs) developed. The social security insurance systems covered all enterprises including both the public sector and private sector from the 1990s. When the enterprises' social insurance premium payments are high, it is thought that the enterprises may choose to transfer the social insurance premiums onto their workers by reducing the workers' wage levels.

Let us consider the development of public security systems in China. The People's Republic of China (PRC) enacted its first social security law in 1951, entitled 'LaoDong BaoXian TiaoLi'. It provided public security for workers in SOEs, and collective-owned enterprises (COEs). The public security systems included (a) pension, (b) health care, (c) work injury compensation, and (d) maternity. These security systems were managed and financially underwritten by the Chinese government. In the period of economic transition, the government reformed the public security systems. To reduce the financial burden on the government, the government changed the government security systems into social security systems, in which the social security funds were established by government, but with contributions from enterprises and workers. The enterprises and workers provided the funds by paying an insurance premium based on wage level. For example, the total pension insurance premium was $28 \%$ of a worker's wage: $20 \%$ was paid by the enterprise, and $8 \%$ was paid by the individual worker. From the 2000 s the regulations for social security systems provided six schemes: (a) pension insurance, (b) health care insurance, (c) unemployment insurance, (d) injury compensation insurance (e) maternity insurance, and (f) the housing fund. Except for unemployment insurance and injury compensation insurance, the cost of insurance premiums for the enterprise and the individual worker was determined according to wage level. Even though the insurance premium charged by enterprises and workers differ by various regions, the data from the Ministry of Human Resources and Social Security of the People's Republic of China show that in 2015 the average social insurance premiums for enterprises were around 30-40\% (Note 1).

How does an enterprise's social security insurance premium affect the workers' wage level? From the Economics perspective, the social security insurance premium can be thought of as a payroll tax. It is usually argued the high 
payroll taxes for enterprises may trigger the enterprises' transfer behavior: the enterprise may transfer the payroll tax burden onto workers by decreasing the workers' wage, or transfer the burden onto the consumer by raising the product price. Thus investigation of the impact of payroll taxes on workers' wage levels is an important issue. Most previous studies indicate that the payroll tax may decrease the workers' wage (Hamermesh, 1979; Gruber, 1994; Fishback and Kantor, 1995; Anderson and Meyer, 2000; Kugler and Kugler, 2003; Yiwamoto and Hamaaki, 2006; and Sakei and Kazegami, 2007), whereas Gruber and Krueger (1991), Gruber (1994, 1997), and Tachibanaki and Yokoyama (2008) found that the impact of the payroll tax on wage is not statistically significant. Yiwamoto and Hamaaki (2006) even find the wage to be higher when the workers in the enterprise had higher health care payroll taxes.

Many published studies investigate the impact of payroll taxes on wage but some issues are neglected. First, in China, the government reformed not only the economic systems but also the public security systems. Along with these reforms, the social security payroll taxes increased greatly since the 1990s. However, the issue of the impact of social security payroll taxes on wage levels in China is not analyzed. This study addresses this neglected area. Second, existing studies analyze the issue for various groups but there is no published study of labor market segmentation across the private sector and the public sector although it is one of the largest features found in economic transition countries, particularly where there exists a pattern of progressive reform as in China (Ma, 2018a; 2018b). This study scrutinizes labor market segmentation and analyzes the issue for China. To address the heterogeneity, initial dependent and endogenous problems, the fixed effects model, the random effects model and the one-step GMM method are used.

This study is structured as follows: Section 2 introduces the channels in which payroll taxes may influence the workers' wage levels, and summarizes the findings of published empirical studies for developed countries. Section 3 gives the methodological framework for the empirical analysis, including models and data. Section 4 presents and explains the calculated descriptive statistical results. Section 5 presents the estimated results and analyzes them. Section 6 presents the conclusions.

\section{Literature Review}

\subsection{The Channels for the Impact of Payroll Taxes on Wages}

According to the partial equilibrium model, the impact of payroll taxes on wages is related to the wage elasticity of labor demand and labor supply (Hamermesh, 1979; Kotlikoff and Summer, 1987; Gruber and Krueger, 1991; Gruber, 1997; Bojas, 2004; Adhikari, Everson and Gray, 2009). When the increase in labor cost significantly affects the enterprise, which means when the wage elasticity of labor demand is greater, the enterprise may reduce the wage level to address the payroll tax rise. In addition, Summers (1989) indicates that when the workers consider the benefit from payroll taxes, a retirement pension, the labor supply may not decrease markedly and thus cause a small reduction in wage level. In the partial equilibrium model the impact of payroll taxes on wage is not clear because the wage elasticity of labor supply and labor demand associated with the payroll taxes differs from individual to individual, and group to group. The issue needs to be tested with an empirical study.

The results of empirical studies on the impact of payroll taxes on wages can be summarized ${ }^{1}$ as follows. Firstly, estimations based on inductive type wage function were employed in the early period. The payroll tax ratio (the ratio of payroll taxes to wage) is utilized as an independent variable. Most empirical studies find payroll taxes negatively affect wages, suggesting enterprises transferred the social insurance burden onto workers. For example, in the UK Hamermesh (1979) finds enterprises immediately transferred 33\% of the social insurance premium burden onto workers. Holmlund (1983) utilized time series data for Sweden to analyze payroll tax reform, which led to a tax increase from $14 \%$ to $40 \%$ : enterprises transferred half of the burden onto workers.

Secondly, empirical studies based on cross-section data analysis methods, Triplett (1983), Smith and Ehrenberg (1983), Asher (1984), and Yiwamoto and Hamaaki (2006) argued that an endogeneity problem persists. From the 1990s many studies addressed the endogeneity problem using an instrumental variable method and difference in difference (DID) method based on a quasi-natural experiment. For example, for the USA Gruber and Krueger (1991), Gruber (1994), Fishback and Kantor (1995), Anderson and Meyer (2000), Gruber (1997), and Sakei and Kazegami, (2007) utilized the changes to worker compensation insurance (Gruber and Krueger, 1991), health care insurance (Gruber, 1994), worker injury compensation law (Fishback and Kantor, 1995), and employment insurance (Anderson and Meyer, 2000). Change to health care insurance was used for Japan (Sakei and Kazegami, 2007). The total social insurance fee was used for Chile (Gruber, 1997) and Columbia (Kugler and Kugler, 2003) as a quasi-natural experiment and to investigate the payroll taxes on wage based on the DID model. However, these empirical study results are not consistent. For example, Fishback and Kantor (1995), Anderson and Meyer (2000), Kugler and Kugler 
(2003), and Sakei and Kazegami (2007) indicate that increased payroll taxes decrease the wage, whereas Gruber and Krueger (1991), and Gruber $(1994,1997)$ found that the impact of the payroll taxes on wage is not statistically significant.

To the authors' knowledge no empirical study on the issue for China, a major economic transition country, has yet been published. Current economic theory and these previous studies suggest two hypotheses. We employ econometric analyses and the results provide new evidence on the issue for China, a country with a developing economy undergoing economic system transition.

H1: The social security payroll taxes negatively affect the workers' wage in China.

As described in Section 2, according to the partial equilibrium model, the impact of payroll taxes on wage is determined by the elasticity of labor supply and demand to wage. It is thought the wage elasticity of the labor supply is small because surplus labor persists in rural China (Minami and Ma, 2010, 2014). The influence of enterprises on wage and employment determination is larger because the collective bargaining influence of the workers' unions on wage is small. Thus enterprises may easily transfer payroll taxes to the workers, which causes the workers' wage to decrease when the payroll tax is higher (H1).

$\mathrm{H} 2$ : The negative influence of social security payroll taxes on wages is greater for the private sector than for the public sector in China.

Two explanations are examined for Hypothesis 2. Firstly, management purpose may differ according to sector. The Chinese labor market is segmented into the public sector and the private sector (Chen, Demurger and Fournier, 2005; Demurger et al. 2007; Luo and Li, 2007; Zhang and Xue, 2008; Ye, Li and Luo, 2011; Demurger, Li and Yang, 2012; and Ma 2009a, 2014, 2015, 2016, 2017, 2018a, 2018b). Enterprises in the public sector may strive to achieve the government's political aims, for example to reduce income inequality, to preserve employment security and promote China's national interests and safety. In contrast, the private sector entrepreneurs and enterprises may prioritise the profit imperative to survive in a competitive market. Therefore, to maximise profit, the transfer of the payroll tax burden onto the worker is higher in the private sector than for the public sector.

Secondly, the influence of the market mechanism on wage and employment determination is greater for the private sector than for the public sector. Therefore, when the social security payroll tax is high, the enterprises in the private sector will immediately adjust their resource allocation, and reduce the labor costs which causes the wage level to decrease.

For these two reasons it is thought that the negative influence of social security payroll taxes on wages may be greater for the private sector than for the public sector $(\mathrm{H} 2)$.

\section{Methodology and Data}

\subsection{Model}

Four kinds of estimated models are utilized in this study to investigate the impact of payroll taxes on wages.

Firstly, the Ordinary Least Squares (OLS) regression model is used:

$$
\ln \mathrm{W}_{\mathrm{i}}=\mathrm{a}+\beta_{\mathrm{I}} \text { Insurance }_{\mathrm{i}}+\beta_{\mathrm{H}} \mathrm{H}_{\mathrm{i}}+\mathrm{v}_{\mathrm{i}}
$$

In equation (1), $\operatorname{lnW}$ stands for the logarithm of wage, $i$ for the enterprise, Insurance for the enterprise's average social insurance premium, $H$ for the enterprise characteristics variables (e.g. K/L, export ratio, firm size, ownership type, and industry sector) and survey year dummy variables. a is the constant term, and $\mathrm{v}$ is the error term. $\beta$ represents the estimated coefficient for each variable.

Secondly, it is argued that there are time invariant factors such as unobserved characteristics (unobserved ability, psychological factors, and special behavior pattern) that may affect the wage. It is thought the bias associated with the heterogeneity problem may remain in the results based on the OLS. To address this problem panel data analysis methods are utilized:

$$
\ln \mathrm{W}_{\mathrm{i}, \mathrm{t}}=\mathrm{a}+\beta_{\mathrm{I}} \text { Insurance }_{\mathrm{i}, \mathrm{t}}+\beta_{\mathrm{H}} \mathrm{H}_{\mathrm{i}, \mathrm{t}}+\varepsilon_{\mathrm{i}}+\mathrm{u}_{\mathrm{i}, \mathrm{t}}
$$

In equation (2), $i$ stands for the enterprise, $t$ for years. $\varepsilon$ stands for the unobserved enterprise characteristic, and $u$ is the real error term. The definitions of $\beta$, Insurance and $H$ are similar to those in equation (1). Because $\varepsilon$ may be time invariant or appear randomly, the fixed effects (FE) model and the random effects (RE) model are utilized.

Thirdly, even though the fixed effects model and random effects model can address the heterogeneity problem, the initial dependent problem and the endogenous problem may remain. The Generalized Method of Moments (GMM) 
can be used to address these econometric problems. The GMM method can produce the consistent parameter estimates for a finite number of time periods ( $\mathrm{T}$ ), and a large cross-sectional dimension (n) (see Arellano and Bond, 1991; Arellano and Bover, 1995; Blundell and Bond, 1998). Because we utilize a short-term (four waves) panel data, the one-step GMM method is used in the study. The one-step GMM method can utilize the lagged variables ( $\mathrm{t}-1$ period) as the instrumental variables to address the endogeneity problem.

Based on Arellano and Bond (1991), the one-step GMM method can be represented as follows:

$\mathrm{n}$

$1 / \mathrm{n} \Sigma \ln \mathrm{W}_{\mathrm{i}, \mathrm{s}}\left[\left(\ln \mathrm{W}_{\mathrm{i}, \mathrm{t}^{-}} \ln \mathrm{W}_{\mathrm{i}, \mathrm{t}-1}\right) \beta \mathrm{w}\right]=0$

$\mathrm{i}=1$

$\mathrm{s}=0,1, \ldots, \mathrm{t}-1 ; \mathrm{t}=2,3, \ldots, \mathrm{T}$

When the lagged dependent variables as instrumental variables are not correlated with lagged $u$, the dynamic panel data analyzed of one-step GMM method can be expressed as follows:

$$
\begin{aligned}
& \Delta \operatorname{lnW}_{\mathrm{it}}=\ln \mathrm{W}_{\mathrm{i}, \mathrm{t}-1}^{\prime} \beta \mathrm{w}^{+} \Delta \mathrm{X}_{\mathrm{i}, \mathrm{t}-1}^{\prime} \beta \mathrm{X}+\Delta \mathrm{u}_{\mathrm{i}} \\
& \mathrm{i}=1,2, \ldots, \mathrm{n}
\end{aligned}
$$

The equation (3.2) is utilized in the study. In equations (3.1), and (3.2), lnW stands for the logarithm of wage, $X$ includes Insurance and $H$ variables in equations (1) and (2), $\beta$ represents the coefficients to be estimated. $\Delta$ stands for the first difference calculated by the "Difference=variable i, $\mathrm{t}$-variable i, t-1", here, variables include the $\operatorname{lnW}, \mathrm{X}$ and $\mathrm{u}$. The initial dependent problem can be addressed by using $\ln \mathrm{W}_{\mathrm{i}, \mathrm{t}-1}$.

Even though the Difference in Difference (DID) method is utilized in previous studies (Gruber and Krueger 1991; Gruber 1994; Fishback and Kantor 1995; Anderson and Meyer 2000; Gruber 1997), during the period from 2004 to 2007 the Chinese government did not implement new reforms of the social security system, therefore it is thought that the DID method is not appropriate for our data from 2004 to 2007. Thus, we employ econometric analyses based on the OLS, the fixed effects model, the random effects model, and one-step GMM method in this study.

Finally, using the estimated results of Insurance, we can provide the evidence for H1.When the coefficient of Insurance is a negative value and is statistically significant, it is indicated that payroll taxes negatively affect workers' wages, therefore H1 is supported. The estimated results of Insurance for the public sector and private sector are used to provide the evidences for $\mathrm{H} 2$. $\mathrm{H} 2$ is supported when the coefficient value of Insurance is greater for the private sector and is statistically significant.

\subsection{Data}

This study uses the Chinese Large and Medium-size Manufacturing Enterprises (CLMME) data, which is fairly similar to the Longitudinal Research Database (LRD) maintained by the U.S. Bureau of the Census. Our dataset comprises all state-owned firms as well as non-state firms with sales exceeding 5 million RMB (about US \$650,000). The sample consists of workers' wage, social security payroll taxes for workers, and other information about enterprises. Data from 2004-2007 is selected because the information on enterprises' social security insurance premium payments can only be obtained from 2004-2007. The row data samples for each survey year are 263,861 in 2004, 257,990 in 2004, 282,063 in 2006 and 312,206 in 2007. Enterprises that did not have complete analyzed information on the main regression variables were deleted. According to the Enterprise Regulations, a firm with less than eight employees is counted in the self-employment category, and is therefore omitted. Observations in the one percent tails of each of the regression variables are omitted to control for the potential influence of outliers. CLMME data is not a panel survey dataset so we utilized the information of the enterprises' address, telephone number and industry code to construct an enterprise panel dataset. The unbalanced panel covers four waves $(2004,2005,2006$, and 2007), the number of the samples appeared for four waves is 167,493 , for three waves is 67,274 , for two waves is 59,680 , for only one wave is 93,554 , the matched total number of the panel dataset sample is 388,001 . The cross-section dataset is used for the OLS, and the unbalanced panel dataset is utilized for the analyses based on a fixed effects model, a random effects model and the one-step GMM method.

The ownership types are classified into five kinds based on the dataset: state owned enterprises (SOE); collectively owned enterprises (COE); privately owned enterprise (POE); foreign owned enterprise (FOE); Hong Kong and Taiwan owned enterprise (HTOE), and other types of enterprise (Other). The public sector comprises SOEs and the private sector includes COE, POE, FOE and HTOE. 
The dependent variable is the logarithm of average pre-tax wage, which is calculated by the total wage bill divided by the number of workers in the enterprise.

Insurance is the ratio of the total social insurance premium charged by enterprises to workers' total wage. In the dataset, the social security insurances include the pension insurance, unemployment insurance and housing fund.

Other control variables are constructed. (1) $K / L$ is calculated as the asset divided by the number of workers. The K/L is used to control for the disparity of enterprise' capital (or technology, skill). (2) Global business may affect workers' wage levels, the Export variable, the ratio of export production value to total revenue, is constructed to control for the global business influence on wages. (3) The enterprise' profit ratio is calculated as the total profit which is calculated by revenue minus cost divided by total sales. It is thought profit may influence wage level because wage is a part of the labor cost. In the perfect competitive market, when other factors are constant, the wage should be lower for enterprises with higher profit. (4) Based on the economies of scale, firm size may affect the revenue, or profit, therefore it may affect workers' wage levels. The firm size dummy variables are based on the revenue: from the first (small size firm) to the third quintiles (large size firm). (5) It is thought that the wage level differs with the industry sector. Twelve kinds of industry sector dummy variables are constructed using the dataset and National Economic Industry Classification Code published in 2002 and 2011. These industry sector dummy variables control for the industry sector disparities. The twelve dummy variables are Mining, Food, Textile, Leather, Timber, Cultural Goods, Chemical, Building Products, Metal, Equipment, Electrical Appliance Manufacturing Industries, and the Energy Industry. (6) Year dummy variables for 2004-2007 are utilized to control for the macroeconomic and policy influences on wage levels. (7) It can be thought that the labor supply and demand differs by regions, and the economic development level differs by regions, therefore province dummy variables (31 provinces and metropolis) (Note 2) are utilized to control the regional disparity for labor markets.

\section{Descriptive Statistics Results}

The descriptive statistics of variables for the public and private sectors are summarized in Table 1 . The mean values of the dependent and independent variables are shown in Table 1. Two-sample t-tests (Snedecor and Cochran, 1989) are employed to investigate the mean value differences of these variables between the public sector and private sector. The P-values and statistical significances are also summarized in Table 1. When the statistical significant level is $1 \%$ or 5\%, it indicates that there remains a mean value difference between the public sector and private sector, which indicates that the enterprise characteristics are significantly different between these two sectors. The main findings are as follows.

Firstly, the logarithm of average monthly wage is higher for the public sector (2.707 Yuan) than for the private sector (2.680 Yuan). The enterprises' social security payroll tax ratio, calculated by the total social security premiums charged by the enterprise divided by the total workers' wage, is higher for the public sector $(34.6 \%)$ than for the private sector $(11.4 \%)$. T-test results show that the p-values are statistically significant at $1 \%$. It is indicated that both the wage difference and social security payroll tax ratio difference between the public sector and private sector remain.

Secondly, the K/L which is calculated by the enterprise asset divided by the number of workers is higher for the public sector $(0.933)$ than for the private sector $(0.331)$, and the p-value is statistically significant at $1 \%$. It is indicated that capital investment is larger for the public sector than for the private sector. This may be because the government provides mainly financial support to enterprises in the public sector.

Thirdly, the export ratio (the ratio of export production value to total revenue) is higher for the private sector (16.1\%) than the public sector $(4.0 \%)$, and the p-value is statistically significant at $1 \%$. It is shown that global business is more active in the private sector.

Fourthly, the profit ratio (calculated by the profit divided by the total sales) is higher for the public sector (3.8\%) than the private sector $(2.8 \%)$, and the p-value is statistically significant at $1 \%$. It indicates that the profit difference between these two sectors remains.

Fifthly, to compare the proportions of small, middle and large-size enterprises between the public sector and private sector, it is observed that the proportion of large-size enterprises is higher for the public sector (42.8\%) than for the private sector $(36.6 \%)$, and the difference is statistically significant at $1 \%$.

Sixthly, the proportion distributions of industry sectors also differ between the public sector and private sector. For example, the proportion of industry 1 (Mining manufacturing industry) is higher for the public sector (6.1\%) than for the private sector $(4.3 \%)$, and the p-value is statistically significant at $1 \%$. 
It is clear that the mean values of social security payroll taxes and wage levels are significantly different between the public sector and private sector, and the disparities of enterprise characteristics between these sectors are significantly marked. Thus, a comparison study between the public sector and private sector is needed on this issue.

Table 1. Descriptive statistics

\begin{tabular}{llllll}
\hline & $\begin{array}{l}\text { Total } \\
(\mathrm{a}+\mathrm{b})\end{array}$ & $\begin{array}{l}\text { Public } \\
(\mathrm{a})\end{array}$ & $\begin{array}{l}\text { Private } \\
(\mathrm{b})\end{array}$ & & $\begin{array}{l}\text { t-test } \\
(\mathrm{a}) \mathrm{vs} .(\mathrm{b})\end{array}$ \\
& & & coef. & \\
\hline lnwage & 2.684 & 2.707 & 2.680 & -8.818 & $* * *$ \\
Insurance & 0.146 & 0.346 & 0.114 & -56.029 & $* * *$ \\
K/L & 0.414 & 0.933 & 0.331 & -26.242 & $* * *$ \\
Export & 0.144 & 0.040 & 0.161 & 96.381 & $* * *$ \\
Profit & 0.029 & 0.038 & 0.028 & -2.819 & $* * *$ \\
Firm size & & & & & \\
\multicolumn{1}{c}{ Small } & 0.297 & 0.361 & 0.287 & -55.311 & $* * *$ \\
Middle & 0.328 & 0.211 & 0.347 & 85.292 & $* * *$ \\
Large & 0.375 & 0.428 & 0.366 & -30.023 & $* * *$
\end{tabular}

Ownership types

Public sector $\quad 0.138$

Private sector $\quad 0.863$

Industry sector

industry $1 \quad 0.04$

$0.061 \quad 0.043$

$-22.807 * * *$

industry2 $\quad 0.081$

$0.088 \quad 0.080$

$-10.390 \quad * * *$

industry3 $\quad 0.119$

$0.039 \quad 0.132$

79.727

industry4 $\quad 0.025$

$\begin{array}{ll}0.004 & 0.029\end{array}$

45.129

$0.012 \quad 0.034$

36.752

0.056

0.054

$-3.089$

$* * *$

industry5 $\quad 0.031$

0.055

0.118

0.156

29.914

0.065

0.072

7.443

$* * *$

industry8 $\quad 0.071$

0.055

0.098

41.693

0.174

0.161

$-9.979$

0.088

0.126

32.849

$* * *$

$\begin{array}{ll}\text { industry11 } & 0.120 \\ \text { industry12 } & 0.046\end{array}$

0.240

0.016

$-340.000$

$* * *$

Survey Year

$\begin{array}{ll}\text { y2004 } & 0.047 \\ \text { y2005 } & 0.059\end{array}$

0.307

0.006

$-470.000 * * *$

0.242

0.030

$-260.000 * * *$ 


$\begin{array}{llllll}\text { y2006 } & 0.424 & 0.247 & 0.452 & 121.3684 & * * * \\ \text { y2007 } & 0.470 & 0.205 & 0.512 & 180.7992 & * * *\end{array}$

Observations $\quad 664,125 \quad 91,415 \quad 572,710$

Notes: (1) Public sector: state owned enterprise (SOE); Private sector: privately owned enterprise (POE), foreign owned enterprise excluding the Hong Kong and Taiwan enterprises (FOE) and Hong Kong and Taiwan owned enterprises (HTOE)

(2) The industry sectors from 1 to 12 are as follows: Mining, Food, Textile, Leather, Timber, Cultural Goods, Chemical, Building Products, Metal, Equipment, Electrical Appliance Manufacturing Industries and Energy Industry.

(3) $*, * * * * *$ : statistical significant levels are $10 \%, 5 \%$, and $1 \%$.

(4) Calculated based on the cross section dataset from 2004 to 2007.

Source: Calculated based on Chinese Large and Medium-size Manufacturing Enterprises (CLMME) dataset from 2004 to 2007.

Let us to observe the relation between the payroll taxes and wage levels based on the tabulation calculations before we employ the econometric analyses on the impact of the social security payroll taxes on pre-tax wages. The mean values of social security payroll tax ratios charged by enterprises and workers' average wage from 2004 to 2007 are shown in Figure 1. It seems that a negative relation between the social security payroll tax and wage does not remain. For example, in the public sector both the payroll tax and average wage are greater in 2007 than 2004 and the tendency is similar in the private sector. However, it should be noticed that the other factors (e.g. capital, labor, firm size, industry sector) that may affect wage levels are not controlled for in these calculations. When these factors are constant, does the social security payroll tax affect the wage? Does there remain a difference in the impact of payroll tax on wage between the public sector and private sector? We will employ the more detailed econometric analyses to answer this question in section 5.

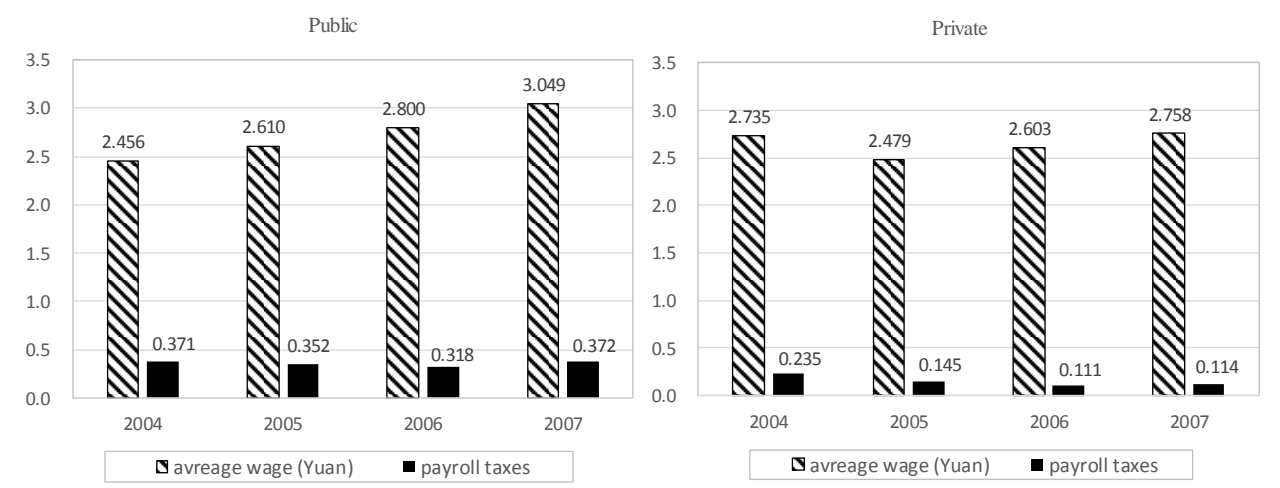

Figure 1. The social security payroll tax ratios of enterprises and average workers' wages from 2004 to 2007

Note: Social security payroll tax ratio is calculated as the total social security premium charged by the enterprise divided by the total workers' wage.

Source: Calculated based on Chinese Large and Medium-size Manufacturing Enterprises (CLMME) dataset from 2004 to 2007.

\section{Results of Econometric Analysis}

\subsection{Results of the Impact of Social Security Payroll Taxes on Wages}

Table 2-1, Table 2-2 shows the results of the impact of social security payroll tax on wages for total samples (the total of enterprises in both the public sector and private sector) using the OLS, fixed effects model (FE), random 
effects model (RE), and one-step generalized method of moments (GMM). To compare these results, we summarize these results in Table 2-1, Table 2-2.

Table 2-1. Results of the impact of social security payroll taxes on wages for total samples (enterprises in both the public sector and private sector)

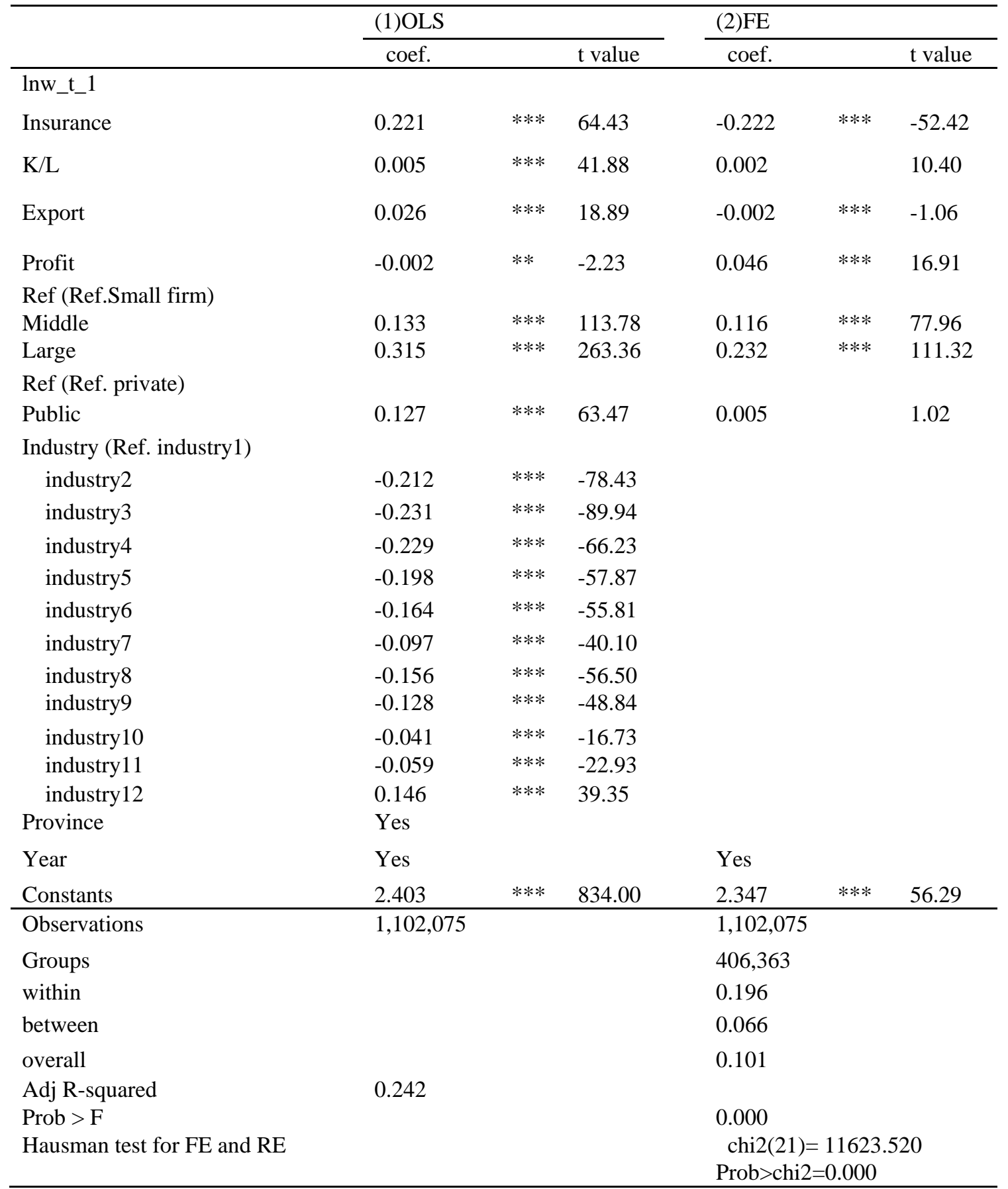

Notes: $(1)^{*}, * *, * * *:$ statistical significant levels are $10 \%, 5 \%$, and $1 \%$.

(2) lnwt_1 shows the logarithms of wage in the prior survey year.

(3) To express clearly, K/L and profit utilized in analyses are actual values divided by 1000 .

(4) The industry classifications from 1 to 12 are as follows: Mining, Food, Textile, Leather, Timber, Cultural Goods, Chemical, Building Products, Metal, Equipment, Electrical Appliance Manufacturing Industries and Energy Industry. 
(5) Year and Province dummy variables are estimated, these results are not expressed in the Table.

(6) OLS: ordinary least squares regression; FE: fixed effects model.

Source: Calculated based on Chinese Large and Medium-size Manufacturing Enterprises (CLMME) dataset from 2004 to 2007.

Table 2-2. Results of the impact of social security payroll taxes on wages for total samples (enterprises in both the public sector and private sector)

\begin{tabular}{|c|c|c|c|c|c|c|}
\hline \multirow{3}{*}{ lnw_t_1 } & \multicolumn{3}{|l|}{ (3)RE } & \multicolumn{3}{|c|}{ (4)one-step GMM } \\
\hline & \multicolumn{2}{|l|}{ coef. } & \multirow[t]{2}{*}{ t value } & \multicolumn{2}{|l|}{ coef. } & \multirow{2}{*}{$\begin{array}{l}\text { t value } \\
114.48\end{array}$} \\
\hline & & & & 1.299 & $* * *$ & \\
\hline Insurance & 0.009 & $* * *$ & 2.70 & -0.416 & $* * *$ & -41.41 \\
\hline $\mathrm{K} / \mathrm{L}$ & 0.004 & $* * *$ & 32.23 & 0.005 & $* * *$ & 6.83 \\
\hline Export & 0.017 & $* * *$ & 10.65 & -0.004 & & -0.48 \\
\hline Profit & 0.009 & $* * *$ & 6.87 & 0.020 & $*$ & 1.90 \\
\hline \multicolumn{7}{|c|}{ Ref (Ref.Small firm) } \\
\hline Middle & 0.135 & $* * *$ & 117.04 & 0.070 & $* * *$ & 15.13 \\
\hline Large & 0.295 & $* * *$ & 214.34 & 0.116 & $* * *$ & 17.98 \\
\hline \multicolumn{7}{|c|}{ Ref (Ref. private) } \\
\hline Public & 0.111 & $* * *$ & 45.37 & -0.008 & & -0.69 \\
\hline \multicolumn{7}{|c|}{ Industry (Ref. industry1) } \\
\hline industry 2 & -0.210 & $* * *$ & -56.55 & & & \\
\hline industry3 & -0.229 & $* * *$ & -64.63 & & & \\
\hline industry 4 & -0.224 & $* * *$ & -46.35 & & & \\
\hline industry5 & -0.198 & $* * *$ & -42.20 & & & \\
\hline industry6 & -0.161 & $* * *$ & -39.33 & & & \\
\hline industry7 & -0.096 & $* * *$ & -29.04 & & & \\
\hline industry8 & -0.153 & $* * *$ & -40.17 & & & \\
\hline industry 9 & -0.125 & $* * *$ & -34.71 & & & \\
\hline industry10 & -0.039 & $* * *$ & -11.47 & & & \\
\hline industry11 & -0.054 & $* * *$ & -15.24 & & & \\
\hline industry12 & 0.180 & $* * *$ & 34.32 & & & \\
\hline Province & Yes & & & & & \\
\hline Year & Yes & & & Yes & & \\
\hline Constants & 2.467 & $* * *$ & 654.08 & -0.628 & $* * *$ & -22.74 \\
\hline Observations & $1,102,075$ & & & 380,102 & & \\
\hline Groups & 406,363 & & & 216,849 & & \\
\hline within & 0.190 & & & & & \\
\hline
\end{tabular}




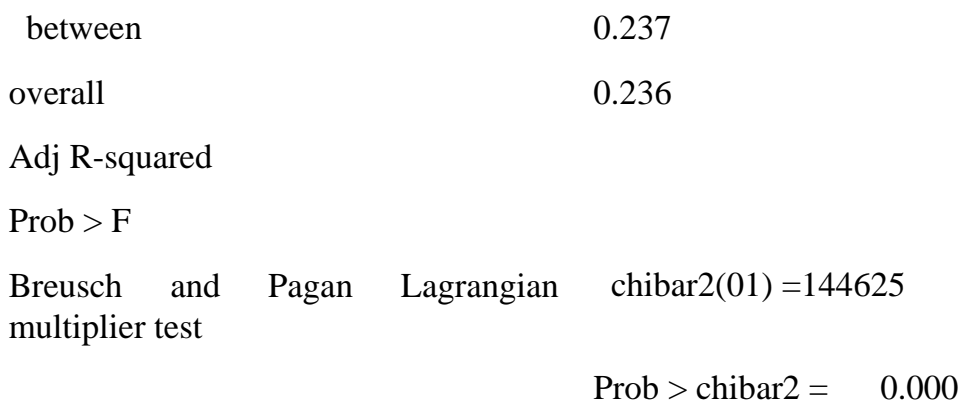

Sargan test of overidentifying restrictions $\operatorname{chi} 2(2)=130.694$

Prob > chi $2=0.000$

Notes: (1) $* * *, * * *:$ statistical significant levels are $10 \%, 5 \%$, and $1 \%$.

(2) lnwt_1 shows the logarithms of wage in the prior survey year.

(3) To express clearly, K/L and profit utilized in analyses are actual values divided by 1000.

(4) The industry classifications from 1 to 12 are as follows: Mining, Food, Textile, Leather, Timber, Cultural Goods, Chemical, Building Products, Metal, Equipment, Electrical Appliance Manufacturing Industries and Energy Industry.

(5) Year and Province dummy variables are estimated, these results are not expressed in the Table.

(6) RE: random effects model: GMM: generalized method of moments.

Source: Calculated based on Chinese Large and Medium-size Manufacturing Enterprises (CLMME) dataset from 2004 to 2007.

Firstly, the F-test and the Breusch and Pagan Lagrangian multiplier test results indicate both the fixed effects model and random effects model are more appropriate than the OLS model. The Hausman test results show that the fixed effects model is superior to the random effects model. Because we used short-term unbalanced panel data, it is thought the one-step GMM method may be most applicable. Even though the tendency of these results are similar, we provide the evidence for the hypothesis testing based on the one-step GMM method.

In the results based on the one-step GMM method, the coefficient of payroll taxes is -0.416 , and it is statistically significant at $1 \%$. The results indicate that payroll tax negatively affects the wage, which indicates that social security payroll taxes may cause the wage level to decrease as enterprises transfer the payroll tax burden onto their worker. These results support H1 (The social security payroll taxes negatively affect workers' wage in China). These results are consistent with Hamermesh (1979), Gruber (1994), Fishback and Kantor (1995), Anderson and Meyer (2000), Kugler and Kugler (2003), Komamura and Yamada (2004), Yiwamoto and Hamaaki (2006), and Sakei and Kazegami (2007) for the developed countries (e.g. USA and Japan), and for developing countries (e.g. Chile). China is both an economy developing country and an economy system transition country and these results provide useful new evidences on the issue.

\subsection{Results of Impact of Social Security Payroll Taxes on Wages by the Public Sector and Private Sector}

Then, the estimated results from the public sector and private sector are used to provide evidence for the $\mathrm{H} 2$. These results are summarized in Table 3-1 (public sector), Table 3-2 (public sector), Table 4-1 (private sector), and Table 4-2 (private sector).

The results of the F-test, the Breusch and Pagan Lagrangian multiplier test, and Hausman test indicate the fixed effects model is superior to the OLS model and the random effects model. Because we used a short-term unbalanced panel data, it is thought the one-step GMM method may be most applicable, we will provide evidence for H2 using the results based on one-step GMM method. We also summarize these results based on four methods of analysis.

Firstly, the coefficients are -0.336 (public sector), and -0.437 (private sector) and they are statistically significant at $1 \%$ based on the GMM method. It is clear that in both the public sector and the private sector, increased social security payroll taxes may decrease the workers' wage level. When the government increases the payroll tax, the enterprises in both the public sector and the private sector may transfer the payroll tax burden onto their workers. 
Secondly, it is clear that the negative effects are different in these two sectors. Concretely, the negative effect of the social security payroll tax is greater for the private sector than for the public sector. These results support $\mathrm{H} 2$.

The results can be explained as follows. First, the motives or agenda of the management teams in the public sector may be different to the purpose of the management teams in the private sector. For example, enterprises in the public sector respond to the government's policy goals (for example, to develop and produce goods to support China's safety and integrity, or to provide employment and stability). Therefore, the government invests the majority of public financial support to the public sector. Enterprises in the public sector do not need to reduce the workers' wage level to respond to the payroll tax rise. Second, in the private sector, the influence of the market mechanism on wage is less than for enterprises in the public sector. For example, during the 2000s employment and the basic wage in the public sector were managed and controlled by the government (Ma, 2016, 2017), and wage adjustment could not be immediately employed to address the payroll tax rise. Enterprises in the private sector may choose to immediately transfer the payroll taxes rise burden onto workers in order to maximise profit.

Table 3-1. Results of the impact of social security payroll taxes on wages for the public sector

\begin{tabular}{|c|c|c|c|c|c|c|}
\hline & \multicolumn{3}{|c|}{ (1)OLS } & \multicolumn{3}{|l|}{ (2)FE } \\
\hline & \multicolumn{2}{|l|}{ coef. } & \multirow[t]{2}{*}{$\mathrm{t}$ value } & \multicolumn{2}{|l|}{ coef. } & \multirow[t]{2}{*}{ t value } \\
\hline lnw_t_1 & & & & & & \\
\hline Insurance & 0.005 & & 0.49 & -0.260 & $* * *$ & -34.94 \\
\hline $\mathrm{K} / \mathrm{L}$ & 0.003 & $* * *$ & 18.96 & 0.001 & $* *$ & 2.72 \\
\hline Export & -0.032 & $* * *$ & -2.77 & 0.044 & $* *$ & 2.40 \\
\hline Profit & -0.001 & & -0.65 & 0.007 & $* * *$ & 2.00 \\
\hline \multicolumn{7}{|c|}{ Ref (Ref.Small firm) } \\
\hline Middle & 0.279 & $* * *$ & 50.82 & 0.105 & $* * *$ & 14.26 \\
\hline Large & 0.602 & $* * *$ & 126.22 & 0.241 & $* * *$ & 24.31 \\
\hline \multicolumn{7}{|c|}{ Industry (Ref. industry1) } \\
\hline industry 2 & -0.225 & $* * *$ & -22.24 & & & \\
\hline industry3 & -0.370 & $* * *$ & -28.79 & & & \\
\hline industry4 & -0.342 & $* * *$ & -10.18 & & & \\
\hline industry 5 & -0.224 & $* * *$ & -11.30 & & & \\
\hline industry 6 & -0.002 & & -0.22 & & & \\
\hline industry7 & -0.074 & $* * *$ & -7.77 & & & \\
\hline industry 8 & -0.198 & $* * *$ & -18.37 & & & \\
\hline industry9 & -0.030 & $* * *$ & -2.66 & & & \\
\hline industry 10 & 0.021 & $* *$ & 2.37 & & & \\
\hline industry11 & 0.108 & $* * *$ & 10.47 & & & \\
\hline industry12 & 0.188 & $* * *$ & 21.77 & & & \\
\hline Province & Yes & & & & & \\
\hline Year & Yes & & & Yes & & \\
\hline Constants & 2.466 & $* * *$ & 237.10 & 2.662 & & 23.50 \\
\hline
\end{tabular}




\begin{tabular}{lcc}
\hline Observations & 88,407 & 88,407 \\
Groups & & 36,351 \\
within & & 0.169 \\
between & 0.056 \\
overall & 0.353 & 0.058 \\
Adj R-squared & & 0.000 \\
Prob > F & chi2 $(20)=2606.010$ \\
Hausman test for FE and RE & Prob $>$ chi $2=0.000$
\end{tabular}

Notes: (1) *,**,***: statistical significant levels are $10 \%, 5 \%$, and $1 \%$.

(2) lnwt_1 shows the logarithms of wage in the prior survey year.

(3) To express clearly, K/L and profit utilized in analyses are actual values divided by 1000.

(4) The industry classifications from 1 to 12 are as follows: Mining, Food, Textile, Leather, Timber, Cultural Goods, Chemical, Building Products, Metal, Equipment, Electrical Appliance Manufacturing Industries and Energy Industry.

(5) Year and Province dummy variables are estimated, these results are not expressed in Table 3.

(6) OLS: ordinary least squares regression; FE: fixed effects model.

Source: Calculated based on Chinese Large and Medium-size Manufacturing Enterprises (CLMME) dataset from 2004 to 2007.

Table 3-2. Results of the impact of social security payroll taxes on wages for the public sector

\begin{tabular}{|c|c|c|c|c|c|c|}
\hline \multirow{3}{*}{ lnw_t_1 } & \multicolumn{3}{|l|}{ (3)RE } & \multicolumn{3}{|c|}{ (4) one-step GMM } \\
\hline & \multicolumn{2}{|l|}{ coef. } & \multirow[t]{2}{*}{ t value } & \multicolumn{2}{|l|}{ coef. } & \multirow{2}{*}{$\begin{array}{l}\mathrm{t} \text { value } \\
12.19\end{array}$} \\
\hline & & & & 0.165 & $* * *$ & \\
\hline Insurance & -0.194 & $* * *$ & -22.27 & -0.336 & $* * *$ & -30.80 \\
\hline $\mathrm{K} / \mathrm{L}$ & 0.002 & $* * *$ & 12.01 & -0.003 & $* * *$ & -4.91 \\
\hline Export & 0.019 & & 1.52 & 0.021 & & 1.05 \\
\hline Profit & 0.006 & $* * *$ & 3.61 & -0.011 & & -1.32 \\
\hline \multicolumn{7}{|c|}{ Ref (Ref.Small firm) } \\
\hline Middle & 0.241 & $* * *$ & 44.01 & 0.058 & $* * *$ & 5.47 \\
\hline Large & 0.513 & $* * *$ & 87.71 & 0.139 & $* * *$ & 9.79 \\
\hline \multicolumn{7}{|c|}{ Industry (Ref. industry1) } \\
\hline industry2 & -0.237 & $* * *$ & -16.19 & & & \\
\hline industry3 & -0.355 & $* * *$ & -19.22 & & & \\
\hline industry4 & -0.344 & $* * *$ & -7.48 & & & \\
\hline industry5 & -0.221 & $* * *$ & -7.83 & & & \\
\hline industry6 & -0.051 & $* * *$ & -3.06 & & & \\
\hline industry7 & -0.066 & $* * *$ & -4.81 & & & \\
\hline
\end{tabular}




\begin{tabular}{lllllll} 
industry8 & -0.190 & $* * *$ & -12.16 & & \\
industry9 & -0.014 & & -0.86 & & \\
industry10 & 0.029 & $* *$ & 2.21 & & \\
industry11 & 0.098 & $* * *$ & 6.66 & & \\
$\quad$ industry12 & 0.209 & $* * *$ & 16.17 & & & \\
Province & Yes & & & & & \\
Year & Yes & & & Yes & \\
Constants & 2.584 & $* * *$ & 178.75 & 2.594 & $* * *$ & \\
\hline Observations & 88,407 & & & 32,440 & & \\
Groups & 36,351 & & & 19,982 & & \\
within & 0.153 & & & & & \\
between & 0.367 & & & & & \\
overall & 0.344 & & & &
\end{tabular}

Adj R-squared

Prob $>$ F

Breusch and Pagan Lagrangian chibar2(01) $=35382.17$

multiplier test

Prob $>$ chibar $2=0.0000$

Sargan test of overidentifying restrictions

$\operatorname{chi} 2(2)=128.3365$

Prob $>$ chi $2=0.000$

Notes: (1) *,**,***: statistical significant levels are10\%, 5\%, and $1 \%$.

(2) lnwt_1 shows the logarithms of wage in the prior survey year.

(3) To express clearly, K/L and profit utilized in analyses are actual values divided by 1000 .

(4) The industry classifications from 1 to 12 are as follows: Mining, Food, Textile, Leather, Timber, Cultural Goods, Chemical, Building Products, Metal, Equipment, Electrical Appliance Manufacturing Industries and Energy Industry.

(5) Year and Province dummy variables are estimated, these results are not expressed in Table 3.

(6) RE: random effects model: GMM: generalized method of moments.

Source: Calculated based on Chinese Large and Medium-size Manufacturing Enterprises (CLMME) dataset from 2004 to 2007.

Table 4-1. Results of the impact of social security payroll taxes on wages for the private sector

\begin{tabular}{|c|c|c|c|c|c|c|}
\hline & \multicolumn{3}{|c|}{ (1)OLS } & \multicolumn{3}{|l|}{ (2)FE } \\
\hline & coef. & & t value & coef. & & $\mathrm{t}$ value \\
\hline \multicolumn{7}{|l|}{ lnw_t_1 } \\
\hline Insurance & 0.244 & $* * *$ & 65.97 & -0.394 & $* * *$ & -41.60 \\
\hline $\mathrm{K} / \mathrm{L}$ & 0.027 & $* * *$ & 72.89 & 0.012 & $* * *$ & 26.32 \\
\hline Export & 0.032 & $* * *$ & 23.52 & -0.003 & & -1.24 \\
\hline Profit & 0.074 & $* * *$ & 23.43 & 0.099 & $* * *$ & 22.63 \\
\hline
\end{tabular}


Ref (Ref.Small firm)

\begin{tabular}{|c|c|c|c|c|c|c|}
\hline Middle & 0.117 & $* * *$ & 99.46 & 0.115 & $* * *$ & 75.43 \\
\hline Large & 0.277 & $* * *$ & 225.30 & 0.228 & $* * *$ & 106.00 \\
\hline \multicolumn{7}{|c|}{ Industry (Ref. industry1) } \\
\hline industry2 & -0.204 & $* * *$ & -73.65 & & & \\
\hline industry3 & -0.223 & $* * *$ & -85.49 & & & \\
\hline industry4 & -0.224 & $* * *$ & -65.17 & & & \\
\hline industry5 & -0.195 & $* * *$ & -56.78 & & & \\
\hline industry6 & -0.171 & $* * *$ & -56.87 & & & \\
\hline industry7 & -0.100 & $* * *$ & -40.66 & & & \\
\hline industry8 & -0.149 & $* * *$ & -53.02 & & & \\
\hline industry9 & -0.133 & $* * *$ & -49.48 & & & \\
\hline industry 10 & -0.043 & $* * *$ & -17.16 & & & \\
\hline industry11 & -0.068 & $* * *$ & -25.74 & & & \\
\hline industry 12 & 0.140 & $* * *$ & 25.84 & & & \\
\hline Province & Yes & & & & & \\
\hline Year & Yes & & & Yes & & \\
\hline Constants & 2.397 & $* * *$ & 808.64 & 2.306 & $* * *$ & 51.00 \\
\hline Observations & $1,013,668$ & & & $1,013,668$ & & \\
\hline Groups & & & & 378,054 & & \\
\hline within & & & & 0.199 & & \\
\hline between & & & & 0.068 & & \\
\hline overall & & & & 0.107 & & \\
\hline Adj R-squared & 0.236 & & & & & \\
\hline Prob $>$ F & & & & 0.000 & & \\
\hline \multirow[t]{2}{*}{ Hausman test } & & & & \multicolumn{3}{|c|}{$\operatorname{chi} 2(20)=9159.65$} \\
\hline & & & & Prob $>$ chi 2 & 0.000 & \\
\hline
\end{tabular}

Note: $(1) * * *, * * *:$ statistical significant levels are $10 \%, 5 \%$, and $1 \%$.

(2) lnw_t_1 shows the logarithms of wage in the prior survey year.

(3) To express clearly, K/L and profit utilized in analyses are actual values divided by 1000.

(4) The industry classifications from 1 to 12 are as follows: Mining, Food, Textile, Leather, Timber, Cultural Goods, Chemical, Building Products, Metal, Equipment, Electrical Appliance Manufacturing Industries and Energy Industry.

(5) Year and Province dummy variables are estimated, these results are not expressed in Table4.

(6) OLS: ordinary least squares regression; FE: fixed effects model.

Source: Calculated based on Chinese Large and Medium-size Manufacturing Enterprises (CLMME) dataset from 2004 to 2007. 
Table 4-2. Results of the impact of social security payroll taxes on wages for the private sector

\begin{tabular}{|c|c|c|c|c|c|c|}
\hline \multirow{3}{*}{ lnw_t_1 } & \multicolumn{3}{|l|}{ (3)RE } & \multicolumn{3}{|c|}{ (4) one-step GMM } \\
\hline & \multicolumn{2}{|l|}{ coef. } & \multirow[t]{2}{*}{$\mathrm{t}$ value } & \multicolumn{2}{|l|}{ coef. } & \multirow{2}{*}{$\begin{array}{l}\mathrm{t} \text { value } \\
109.38\end{array}$} \\
\hline & & & & 1.295 & $* * *$ & \\
\hline Insurance & 0.041 & $* * *$ & 10.99 & -0.437 & $* * *$ & -35.47 \\
\hline $\mathrm{K} / \mathrm{L}$ & 0.020 & $* * *$ & 56.56 & 0.016 & $* * *$ & 14.53 \\
\hline Export & 0.020 & $* * *$ & 12.79 & -0.004 & & -0.54 \\
\hline Profit & 0.091 & $* * *$ & 27.79 & & & \\
\hline \multicolumn{7}{|l|}{ Ref (Ref.Small firm) } \\
\hline Middle & 0.125 & $* * *$ & 106.45 & 0.140 & $* * *$ & 9.61 \\
\hline Large & 0.270 & $* * *$ & 192.25 & 0.069 & $* * *$ & 14.62 \\
\hline Industry (Ref. industry1) & & & & 0.112 & $* * *$ & 16.84 \\
\hline industry2 & -0.203 & $* * *$ & -53.83 & & & \\
\hline industry3 & -0.222 & $* * *$ & -62.48 & & & \\
\hline industry4 & -0.219 & $* * *$ & -46.19 & & & \\
\hline industry5 & -0.195 & $* * *$ & -41.80 & & & \\
\hline industry6 & -0.166 & $* * *$ & -40.21 & & & \\
\hline industry7 & -0.099 & $* * *$ & -29.51 & & & \\
\hline industry 8 & -0.147 & $* * *$ & -38.31 & & & \\
\hline industry9 & -0.129 & $* * *$ & -35.68 & & & \\
\hline industry 10 & -0.041 & $* * *$ & -11.92 & & & \\
\hline industry 11 & -0.060 & $* * *$ & -16.99 & & & \\
\hline industry12 & 0.168 & $* * *$ & 22.94 & & & \\
\hline Province & Yes & & & & & \\
\hline Year & Yes & & & Yes & & \\
\hline Constants & 2.456 & $* * *$ & 641.80 & -0.626 & $* * *$ & -21.85 \\
\hline Observations & $1,013,668$ & & & 347,662 & & \\
\hline Groups & 378,054 & & & 198,304 & & \\
\hline within & 0.194 & & & & & \\
\hline between & 0.229 & & & & & \\
\hline overall & 0.230 & & & & & \\
\hline \multicolumn{7}{|l|}{ Adj R-squared } \\
\hline \multicolumn{7}{|l|}{ Prob $>$ F } \\
\hline \multirow[t]{2}{*}{ Breusch and Pagan Lagrangian multiplier test } & \multicolumn{3}{|c|}{$\operatorname{chibar} 2(01)=2.0 \mathrm{e}+05$} & & & \\
\hline & Prob $>$ chil & $2=$ & 0.0000 & & & \\
\hline \multirow[t]{2}{*}{ Sargan test of overidentifying restrictions } & & & & \multicolumn{3}{|c|}{$\operatorname{chi} 2(2)=1127.323$} \\
\hline & & & & \multicolumn{3}{|c|}{ Prob $>$ chi $2=0.000$} \\
\hline
\end{tabular}


Note: $(1) *, * *, * * *$ : statistical significant levels are $10 \%, 5 \%$, and $1 \%$.

(2) lnwt_1 shows the logarithms of wage in the prior survey year.

(3) To express clearly, K/L and profit utilized in analyses are actual values divided by 1000.

(4) The industry classifications from 1 to 12 are as follows: Mining, Food, Textile, Leather, Timber, Cultural Goods, Chemical, Building Products, Metal, Equipment, Electrical Appliance Manufacturing Industries and Energy Industry.

(5) Year and Province dummy variables are estimated, these results are not expressed in Table4.

(6) RE: random effects model: GMM: generalized method of moments.

Source: Calculated based on Chinese Large and Medium-size Manufacturing Enterprises (CLMME) dataset from 2004 to 2007.

\section{Conclusions}

The Chinese government enforced public security system reform during the economic transition period and as a result the social security insurance premium, which can be thought of as a payroll tax, rose to nearly $40 \%$ of total wage. It is thought enterprises may transfer payroll taxes onto workers by reducing the workers' wages. Does the level of social security payroll taxes influence the level of wage in China? This paper employs an empirical study using enterprise panel survey data from 2004 to 2007 to provide the evidence. The fixed effects model, random effects model and the GMM model are used to address the heterogeneity, initial dependent and endogenous problems. The main findings are as follows.

First, in general, it is clear that the social security payroll tax negatively affects the workers' wage level, which indicates that Chinese enterprises may transfer the payroll tax burden onto their workers. Therefore, H1 is supported.

Second, the effect of the social security payroll tax on wages differs for the public sector and private sector. It is found that even though increased social security payroll tax may decrease the workers' wage level in both the public and private sectors, the negative effect is greater for the private sector than for the public sector: $\mathrm{H} 2$ is supported. This may be because the aims of enterprise management and the influence of market mechanism on wage determination differ for the public sector and the private sector.

The results of this empirical study suggest some policy implications. The results indicate that an increased social security insurance premium may negatively affect workers' wage levels as enterprises transfer the social security insurance burden onto workers (particularly enterprises in the private sector), which may decrease the wage, and decrease the consumption of goods leading to a slowing down of economic growth. The Chinese government reformed the public security systems to address the problem of an ageing population. With these reforms, the social security insurance premium increased for both workers and enterprises. The balance of the conflicting responsibilities of the government, enterprises and workers is an important issue to address. The influence of the labor demand side (enterprises) on wage determination is greater than for the labor supply side (workers) because of the surplus labor in the rural regions and the feeble influence of unionized collective bargaining on wage levels in China. It is thought that when the labor supply wage elasticity is small, the enterprise may easily transfer the social security payroll tax burden onto workers. Therefore, the government should consider alternative ways of funding or increasing the social insurance fund other than by increasing the insurance payroll taxes on enterprises.

The public sector and private sector labor market segments show different results for the impact of social security payroll taxes on wage levels. Notably, the extension of social security coverage from the public sector to the private sector increases the well being of workers in the private sector, but the burden of social security system reform is greater for workers in the private sector. This growing inequality requires a timely solution.

Finally, the enterprise panel data is limited: the impact of payroll taxes on wage is only analyzed from 2004 to 2007. From 2015 the Chinese government decreased the social security premium and detailed analysis using long-term panel data and a further study of the consequences using the quasi-natural experiment method (e.g. the DID method) is needed. This study suggests enterprises may reduce the workers' wage level to compensate for the increase in social security payroll taxes. The effects of social security reform on employment or production prices, for example reduction in employment of low-skilled workers or to increase the production price, may usefully be considered in future research.

\section{Acknowledgements}

JSPS KAKENHI Grant Number JP16K03611 and Grant Number JP18H00863 supported this research. We are 
grateful to Professor Takashi Oshio (Hitotsubashi University), Associate Professor Jie Chen (Institute of Population and Labor Economics, Chinese Academy of Social Sciences) for their helpful comments and suggestions in the international workshop on "Pension Reform: Comparison with China and Japan" in Beijing, China in 2018. I also acknowledge the anonymous referees and editors of the Journal for their many helpful comments and suggestions, and Dr. Richard Lingwood for his helpful editing work.

\section{References}

Adhikari, D. R., Everson, W., \& Gray, L. (2009). Effect of unemployment insurance tax on wages and reallocation of labour. Applied Economics Letters, 16(2), 147-150. https://doi.org/10.1080/13504850601018247

Anderson, P., \& Meyer, B. (2000). The effects of the unemployment insurance payroll tax on wages, employment, claims and denials. Journal of Public Economics, 78(1), 81-106. https://doi.org/10.1016/S0047-2727(99)00112-7

Arellano, M., \& Bond, S. (1991). Some tests of specification for panel data: Monte Carlo evidence and an application to employment equations. Review of Economic Studies, 58(2), 277-298. https://doi.org/10.2307/2297968

Arellano, M., \& Bover, O. (1995). Another look at the instrumental variable estimation of error-components models. Journal of Econometrics, 68(1), 29-51. https://doi.org/10.1016/0304-4076(94)01642-D

Asher, M. A. (1984). On the estimation of payroll tax incidence: Comments. Southern Economic Journal, 50(4), 1224-1230. https://doi.org/10.2307/1058452

Blundell, R., \& Bond, S. (1998). Initial conditions and moment restrictions in dynamic panel data models. Journal of Econometrics, 87(1), 115-143. https://doi.org/10.1016/S0304-4076(98)00009-8

Bojas, G. (2004). Labor Economics (3rd ed.). McGraw-Hill/Irwin.

Chen, G., Demurger, S., \& Fournier, M. (2005). Wage differentials and ownership structure of China's enterprises. World Economic Paper, 6, 11-31. (In Chinese)

Demurger, S., Fournier, M., Li, S., \& Wei, Z. (2007). Economic liberation with rising segmentation in China's urban labor market. Asian Economic Papers, 5(3), 58-103. https://doi.org/10.1162/asep.2007.5.3.58

Demurger, S., Li, S., \& Yang, J. (2012). Earning differentials between the public and private sectors in China: exploring changes for urban local residents in the 2002s. China Economic Review, 23, 138-153. https://doi.org/10.1016/j.chieco.2011.08.007

Fishback, P., \& Kantor, S. E. (1995). Did workers pay for the passage of Workers' Compensation Law? Quarterly Journal of Economics, 110(3), 713-742. https://doi.org/10.2307/2946697

Gruber, J. (1994). The incidence of mandated maternity benefits. American Economic Review, 84(3), 622-41.

Gruber, J. (1997). The incidence of payroll taxation: Evidence from Chile. Journal of Labor Economics, 15(3), 72-101. https://doi.org/10.1086/209877

Gruber, J., \& Krueger, A. (1991). The incidence of mandated employer-provided insurance: Lessons from workers' compensation insurance. In Bradford, D. (Ed.), Tax policy and the economy, 5, 111-44. Cambridge, Mass.: MIT Press. https://doi.org/10.1086/tpe.5.20061802

Hamermesh, D. (1979). New estimates of the incidence of the payroll tax. Southern Economic Journal, 45(1-4), 1208-19. https://doi.org/10.2307/1056965

Holmlund, B. (1983). Payroll taxes and wage inflation: The Swedish experience. Scandinavian Journal of Economics, 85(1), 1-15. https://doi.org/10.2307/3439907

Komamura, K., \& Yamada, A. (2004). Who bears the burden of social insurance? Evidence from Japanese Health and Long-term Care Insurance Data. Journal of the Japanese and International Economies, 18(4), 565-581. https://doi.org/10.1016/j.jjie.2004.08.004

Kotlikoff, L., \& Summer, L. (1987). Tax incidence. In Auerbach, A., \& Feldstein, M. (Eds.), Handbook of Public Economics, 2. 1043-1092.

Kugler, A., \& Kugler, M. (2003). The labor market effects of payroll taxes in a middle-income country: Evidence from Colombia. CEPR Discussion Paper, No.4046.

Luo, C., \& Li, S. (2007). Human capital, industrial features and income inequality. Management World, 10, 20-30. 
(In Chinese)

Ma, X. (2009). The enterprise ownership reforms and the change of wage structure in China: Comparison of gender wage profiles differentials by ownership. Journal of Chinese Economic Studies, 6(1), 48-63. (In Japanese)

Ma, X. (2014). Wage policy: economy transition and wage differentials of sectors. In Nakagane, K. (Ed.), How did Chinese economy changed? Evaluation of economic systems and policies in post-reform period. Tokyo: Kokusai Shoin Co., Ltd. (In Japanese)

Ma, X. (2015). Economic transition and wage differentials between public and private sectors in China. China-USA Business Review, 14(10), 477-494. https://doi.org/10.17265/1537-1514/2015.10.001

Ma, X. (2016). Changes of Wage Structures in Chinese Public and Private Sectors: 1995-2007. Management Studies, 4(6), 243-255. https://doi.org/10.17265/2328-2185/2016.06.002

Ma, X. (2017). Labour Market Segmentation by Ownership Types and Gender Wage Gap in Urban China: Evidence from CHIP2013. Economic and Political Studies, 5(3), 305-325. https://doi.org/10.1080/20954816.2017.1345167

Ma, X. (2018a). Labor Market Segmentation by Industry Sectors and Wage Gaps between Migrants and Local Urban Residents in Urban China. China Economic Review, 47, 96-115. https://doi.org/10.1016/j.chieco.2017.11.007

Ma, X. (2018b). Economic Transition and Labor Market Reform in China, Palgrave Macmillan (forthcoming).

Sakei, M., \& Kazegami, S. (2007). An analysis on the burden of health care insurance. Health and Social, 42(3), 235-248. (In Japanese)

Smith, R. S., \& Ehrenberg, R. G. (1983). Estimation wage-fringe trage-offs: Some data problems. In Triplett, J. E. (Ed.), The Measurement of Labor Cost. University of Chicago Press.

Snedecor, G. W., \& Cochran, W. G. (1989), Statistical Methods, Iowa State University Press.

Tachibanaki, T., \& Yokoyama, Y (2008). The Estimation of the Incidence of Employer Contribution to Social Security in Japan. Japanese Economic Review, 59(1), 75-83. https://doi.org/10.1111/j.1468-5876.2007.00380.x

Triplett, J. E. (1983). The measurement of labor cost. University of Chicago Press. https://doi.org/10.7208/chicago/9780226812595.001.0001

Ye, L., Li, S., \& Luo, C. (2011). Industrial monopoly, ownership and enterprises wage inequality: An empirical research based on the first national economic census of enterprises data. Management World, 4, 26-36. (In Chinese)

Yiwamoto, Y., \& Hamaaki, J. (2006). An analysis on the burden of social insurance: From economics perspective. Social Security Studies, 42(3), 204-218. (In Japanese)

Zhang, J., \& Xue, X. (2008). State and non-state sector wage differentials and human capital contribution. Economic Research, 4, 15-25. (In Chinese)

\section{Notes}

Note 1 . Here, it should be noticed that the lowest wage level for the payroll taxes differs by the regions.

Note 2. The regions compose of Beijing, Tianjin, Hebei, Shanxi, Neimenggu, Liaoning, Jilin, Helongjiang, Shanghai, Jiangsu, Zherjiang, Anhui, Fujian, Jiangxi, Shandong, Hernan, Hubei, Hunan, Duangdong, Guangxi, Hainan, Chongqing, Xichuan, Guizhou, Yunnan, Xizang, Shannxi, Gansu, Qinghai, Ningxia, Xinjiang.

Note 3. Refer to Kotlikoff and Summer (1987), Gruber (1997), Bojas (2004), Yiwamoto and Hamaaki (2006), Sakei and Kazegami (2007) and Adhikari, Everson and Gray (2009). 